\title{
PAWEŁ ZIELIŃSKI
}

Akademia im. Jana Dtugosza

$w$ Częstochowie

\section{THE EDUCATION \\ OF THE VIETNAMESE MINORITY IN POLAND}

\begin{abstract}
Zieliński Paweł, The Education of the Vietnamese Minority in Poland [Edukacja mniejszości wietnamskiej w Polsce]. Studia Edukacyjne nr 33, 2014, Poznań 2014, pp. 393-412. Adam Mickiewicz University Press. ISBN 978-83-232-2879-0. ISSN 1233-6688
\end{abstract}

Analysis of the Vietnamese minority education in Poland in the context of the objectives of intercultural pedagogy showed that it varies depending on the wave of the population migration to Poland. The Vietnamese from the first wave of migration (since the 1950s through the 1970s) with multigenerational families are mostly integrated into Polish society, in contrast to the Vietnamese from the second wave (initiated in the 1990s). This has resulted not so much from a conscious policy of the Polish state on the delivery of intercultural education, but on a confluence of a variety of factors, the most important of which turned out to be the educational and intrinsic activity of the Vietnamese themselves. The Vietnamese minority in Poland has retained their national identity and provide family education in line with the Confucian patterns.

Key words: intercultural and multicultural education, Vietnamese education in Poland, educational attitudes of Vietnamese, ethnic and religious minorities, Confucian, Taoist and Buddhist education

\section{Introduction}

In the article I referred to a wide understanding of education, which is treated by eminent Polish educators as multidimensional processes. Those processes are shaping the evolving man in order to consciously enrich the social community and self-develop his own potential. According to Zbigniew Kwieciński there are many of such processes. It is worth to mention here: globalization, nationalization, state control, collectivization, politicization, bureaucratization and professionalization, socialization, enculturation and personalization, education and juridification, learning, humanization 
and hominization. ${ }^{1}$ All of these processes in a greater or lesser extent, are also associated with Vietnamese minority education in Poland and should be taken into account when we are analyzing the specified topic. The main objective of this thesis, in addition to presenting research results stub Polish scientists and other research related directly or indirectly to the subject of the analysis is capturing the regularity of a multidimensional Vietnamese minority education in Poland. In particular, in terms of conclusion whether and to what extent Vietnamese minority education in Poland is intercultural?

From a methodological point of view, the thesis has a problematic and also synthetic nature. It also has an interdisciplinary character, as I refer to the findings of pedagogical and other border sciences. This can not only enrich the pedagogy itself, but also the others sciences and practice of teaching. ${ }^{2}$ In this article I analyze a broad pool of research - related to the subject of fixed issues. I refer to my own research, which results have been published in several articles on Vietnamese education and the Vietnamese themselves, research which were carried out under my supervision and research academics representing the social sciences and humanities as well as government reports and various organizations.

Without a doubt, Vietnamese minority education in Poland is connected with the research problems of multicultural and intercultural education. Multicultural education related to educational and cultural context of ethnic and nationalist living in developed countries as wrote by Zbyszko Melosik is associated with ideology, politics and cultural changes. Although decades elapsed, it is difficult to find "radical optimism" in matters related to the relationship between identity and minorities education and the dominant mainstream culture and pedagogy of highly developed countries. Here, we can indicate different strategies to overcome this problem by rich countries: conscious assimilation of minorities, isolating newcomers, moreover some of countries are trying to revitalize ethnic, but also sometimes it comes to absorb the ethnic identity by the civilization and culture of consumer and liberal societies. ${ }^{3}$ Similarly, the problem is perceived by Tomasz Szkudlarek, who wrote about the approach of assimilation, isolation, and related to intercultural education. He noticed that those approaches are devising new models of relations between cultures related to the postmodern understand-

${ }^{1}$ Z. Kwieciński, Socjopatologia edukacji [Sociopathology of education], Warszawa 1992, p. 13-17.

2 S. Palka, Badania z pedagogiki i pogranicza innych nauk [Research in Pedagogy and borderline other sciences], [in:] Podstawy metodologii badan w pedagogice [Fundamentals of research methodology in education], ed. S. Palka, Gdańsk 2010, p. 338-353.

${ }^{3}$ Z. Melosik, Teoria i praktyka edukacji wielokulturowej [Theory and practice of multicultural education], Kraków 2007, p. 7. 
ing of the difference, according to the assumptions of critical pedagogy. 4 Jerzy Nikitorowicz has already noticed, together with scholars mentioned before that in a world of continual migration and multicultural environments there is a need to especially take care of the so-called intercultural competence allowing members of the cultures to be released from their own cultural conventions, to enable dialogue and intercultural exchange, strive to open their cultures, to overcome myths and negotiate prejudices, to collaborate and shape tolerant attitudes. ${ }^{5}$ Intercultural education can be realized first of all in the process of learning about yourself and your culture, then the perception of others. It is important to appeal to a variety of theories, for example: integration, intercultural contact, dialogue and cooperation in direct or indirect contact. ${ }^{6}$ Nikitorowicz also presented strategies for multicultural and intercultural education, recognizing the complex field of interactions in culturally diverse regions. ${ }^{7}$ There are taking place processes of ethnocentric and isolation alike as assimilation and integration. As Bogusław Śliwerski wrote "the aim of intercultural pedagogy is to create equal living conditions for different cultural and ethnic groups living within a given society". 8 In developed Western countries such as Sweden, it was assumed that the unit itself has the right to choose a Swedish identity or confirm their own cultural identity, which also contains the ethnic identity. The concept of multiculturalism was replaced here by the concept of integration, the same allowing the possibility of isolationism. The integration should be a "voluntary choice", which in the case of minority isolation (like the Muslim minority) may lead to increased social tensions. The public life of individuals their right to equality and freedom are treated on the basis of similarities. All differences in cultural or religious should be exhibited in the home, on the grounds of the private sector. However, according to commentators, this approach reinforces the differences and undermines the integration of immigrants with

4 Vide: T. Szkudlarek, Pedagogika międzykulturowa, [Intercultural pedagogy], [in:] Pedagogi$k a$ [The pedagogy], vol. 1, eds Z. Kwieciński, B. Śliwerski, Warszawa 2004, p. 418.

${ }^{5}$ J. Nikitorowicz, Edukacja międzykulturowa [The Intercultural Education], [in:] Encyklopedia pedagogiczna XXI wieku [Pedagogical Encyclopedia XXI Century], vol. 1, A-F, ed. T. Pilch, Warszawa 2003, p. 934.

${ }^{6}$ J. Nikitorowicz, Edukacja międzykulturowa w przestrzeni regionalnej, europejskiej i planetarnej [Intercultural Education in the regional, European and planetary], [in:] Nauki pedagogiczne $w$ Polsce. Dokonania, problemy, wspótczesne zadania, perspektywy [Pedagogical Science in Poland. Achievements, problems, contemporary tasks, perspectives], eds E. Lewowicki, M.J. Szymański, Kraków 2004, p. 167.

${ }^{7}$ J. Nikitorowicz, Pogranicze. Tożsamość. Edukacja międzykulturowa [Borderland. Identity. Intercultural Education], Białystok 1995, p. 126-137.

8 B. Śliwerski, Wspótczesne teorie i nurty wychowania [Contemporary theories and trends of education], Kraków 1998, p. 292. 
Swedish society. ${ }^{9}$ Thus, it seems that integrating minorities into society while maintaining their own identities and differences is more appropriate way of intercultural education in the era of globalization.

Research and analysis of the problem of Vietnamese minority education in Poland, in addition to mentioned contexts of a particular culture, also takes into account school education of children and youth from Vietnamese and Polish - Vietnamese families.

\section{Vietnamese Diaspora}

The number of Vietnamese migrants in the world is estimated that: over a million Vietnamese are living in the United States of America, over half a million in France, more than 100,000 in Canada and fewer than 100,000 in Germany. Then Poland was mentioned with the amount of about 25-35 thousand of people, where about $50 \%$ were illegal immigrants. ${ }^{10}$ Recent studies and data suggest that the Czech Republic should also be considered, as the number of Vietnamese people there is now greater than in Poland, although the influx was also inhibited, due to the introduction of the amended Law for Foreigners. ${ }^{11}$ The first major migration of Vietnamese took place in the years: 1949-1954, mainly to France and was associated with the escape of the colonial administration elite and their families from the country which was following communist ideology. The largest migration took place in the years: $1975-1983^{12}$ and had of political and economic refugees nature.

Poland was reached in principle by two great and stretched during the Vietnam migration waves, which at the beginning of the XXI century meant that the Vietnamese were the fourth largest national group of migrants in

${ }^{9}$ A. Gromkowska-Melosik, Mniejszość muzutmańska w Szwecji: między ekstremistycznym izolacjonizmem a procesami reprodukcji ekonomicznej [Muslim minority in Sweden: between extremist isolationism and economic reproduction processes], Studia Edukacyjne, 2013, 26, p. 67-69, 76.

10 P. Zieliński, Edukacja międzykulturowa Wietnamczyków w Polsce z uwzględnieniem dzieci $z$ rodzin polsko-wietnamskich [Intercultural education Vietnamese in Poland also regarding children from Polish-Vietnamese families], Prace Naukowe Akademii im. Jana Długosza w Częstochowie, Pedagogika, 2010, XIX, p. 177.

11 G. Szymańska-Matusiewicz, Niezupetnie bliźniacze społeczności. Wietnamczycy w Polsce $i$ Czechach [Not exactly the twin communities. Vietnamese in Poland and the Czech Republic], Centrum Studiów Polska - Azja, http://www.polska-azja.pl/2013/04/22/g-szymanskamatusiewicz-niezupelnie-blizniacze-spolecznosci-wietnamczycy-w-polsce-i-czechach/, [access: 31.03.2014].

12 T. Halik, Polska i Wietnam [Poland and Vietnam], [in:] Migranci w polskim spoteczeństwie [Migrants in the Polish society], eds T. Halik, A. Kosowicz, M. Marek, Warszawa 2009, p. 110. 
Poland. ${ }^{13}$ Various authors provided different figures concerning the number of Vietnamese in Poland. These figures are ranged between 13-15 thousand or even 60,000 people. The inaccuracy of these estimates was an result of the inclusion of different eligibility criteria staying Vietnamese in Poland and other factors. When only official statistics were taken into account from Poland, European Union and Vietnam, the figure was around 15,000 legal migrants holding Polish citizenship or residence permission in our country. When you take into account also the Vietnamese without such status, illegally working or residing in Poland, the number already increased to 25-35 thousand. ${ }^{14}$ This amount of Vietnamese in Poland seemed to be probable15, but according to some sources numbers were even higher. In the second decade of the twenty-first century the downward trend was marked and the Vietnamese left part of the Poland and in their place are increasingly occupy by the Chinese. Currently, more Vietnamese is living in the Czech Republic than in Poland and their number is estimated there for 60-80 thousand people. ${ }^{16}$

\section{The waves of Vietnamese immigrants in Poland}

The first wave of migration to the Polish Vietnam began in the fifties and lasted until the seventies. Vietnamese students and PhD students have had the opportunity to continue their education and professional work placement under commitments and agreements between the constituent as a communist country of Vietnam and the countries of the so-called "the socialist camp". The first step of staying of young Vietnamese in Poland mainly was focused on courses completion at the Polish Language School in Łódź and adaptive clusters in Szklarska Poręba. Next step for the Vietnamese was to finish in Poland some vocational courses and studies. ${ }^{17}$ Vietnamese students and postgraduates were educated in Poland mainly in technical fields, such as mining and geology, shipbuilding, shipping and maritime transport. ${ }^{18}$ In the early eighties, approximately 200 Vietnamese per year had

13 A. Chodubski, Wyzwania migracyjne we wspótczesnej Europie [Migration Challenges in Contemporary Europe], Przegląd Polsko-Polonijny, 2011, 2, p. 40.

${ }^{14}$ Ibidem, p. 107-108.

15 Społeczność wietnamska w Polsce. Polityka migracyjna Wietnamu. Raport [The Vietnamese community in Poland. Migration policy in Vietnam. The report], Warsaw, June 2007, p. 35-36.

16 G. Szymańska-Matusiewicz, Niezupetnie bliźniacze społeczności [Not exactly the twin communities].

17 W. Olszewski, Historia Wietnamu [History of Vietnam], Wrocław 1991, p. 433.

18 Spoteczność wietnamska w Polsce [The Vietnamese community in Poland], p. 37. 
come to Poland and by the end of the nineties about 4500 Vietnamese evolved in Poland. Many of them have been in our country permanently or returned here later and founded a family. These are educated people, even holding PHD degrees, and sometimes doctorate degree. They know perfectly the Polish language, history and culture of our country. In the Vietnamese community they are often leaders, in Poland they have also educated their children and even grandchildren. ${ }^{19}$ The image of the Vietnamese as a "capable, hardworking, polite, quiet" 20 man formed under the influence of the social impact of the representatives of this wave of migration.

After 1989 and the transformation of the political and socio-economic Poland, especially in the nineties there was a second big wave of Vietnamese migration but the specifics distinct from the previous one. The time of early capitalism encourage private initiative in the field of trade and catering and especially those areas dealt with the Vietnamese incoming to our country. They were not especially interested in legalizing their stay, as well as integrating with communities of already settled Vietnamese or Polish society. Their stay was treated as extending but still temporary stay. Often they planned further migration, especially for wealthier Germany and other Western countries. Vietnamese nationals staying illegally in Poland did not pay taxes, earned money usually was allocated for their families and communities in Vietnam or for illegal crossing of the border with Germany. ${ }^{21}$ Vietnamese of a second wave of migration were people far less educated than those in from the first one, usually they didn't know the western culture and languages, including Polish. Their presence was visible on the markets, bazaars, bars and restaurants of large cities, especially the Mazowieckie province. ${ }^{22}$ As Teresa Halik wrote, Poles began change opinion regarded the Vietnamese people. Also Vietnamese have slightly different characteristics added to the previous determination of the type: "resourceful, agile, with business know-how". ${ }^{23}$ The second wave of Vietnamese migration was still in the first decade of the twenty-first century, then weakened due to the economic crisis and a more restrictive policy of the Poland with respect to for-

\footnotetext{
${ }^{19}$ T. Halik, Polska i Wietnam [Poland and Vietnam], p. 108-109.

20 Ibidem.

${ }^{21}$ Spoteczność wietnamska w Polsce [The Vietnamese community in Poland], p. 38.

22 T. Halik, Polska i Wietnam [Poland and Vietnam], p. 109.

${ }^{23}$ Ibidem. It should be underlined that the Vietnamese Wholesaler clusters, for example Wólka Kosowska, stimulated the development of local entrepreneurship and community by offering, among others, employment of Poles. vide: A. Grzymała-Kazłowska, Między jednościa a wielością: integracja odmiennych grup i kategorii imigrantów w Polsce [Between unity and multiplicity: the integration of the different groups and categories of migrants in Poland], Warszawa
} 2008, p. 262. 
eign migrants. This was also connected to the implementation of the new directives in the field of foreign migration after the Polish accession to the European Union.

In recent decades, in addition to economic migrants Poland was reached by the contract staff, learners and political refugees. Also in the twenty-first century Poland accepted students from Vietnam without any fees. For example, in the academic year 2003/2004 in Poland were educated 266 Vietnamese as Polish language students, undergraduate and graduate students. Some of them paid for their education. In addition, Polish universities, such as: Jagiellonian University, Warsaw University, Lodz University, Adam Mickiewicz University in Poznań, Warsaw and Silesia University of Technology, AGH in Kraków or University of Agriculture in Szczecin - are working directly with Vietnamese universities. ${ }^{24}$

\section{The historical and contemporary context of education in Vietnam}

The traditional culture of not Vietnam but also Japan and Korea is linked mainly to China. These compounds, as well as the beginnings of Vietnamese education were marked in ancient times. During the ancient times, Vietnamese education itself was performed until the end of the first millennium of our era either in China, such as a university studies or under the Chinese supervision of subordinate to the Chinese empire Vietnam. Małgorzata Pietrasiak pointed out the three educational systems developed in this country: the feudal, colonial and folk one. ${ }^{25}$

The feudal system was closely associated with Confucianism, philosophical-religious system derived from the Chinese sage - Confucius (Kong Fuzi, 551-479 BC). Confucianism was regarded in the culture associated with China for many centuries as the scientific worldview, in contrast to the Taoist and Buddhist. This system had a clearly materialistic and collectivist character, although you can also find out other elements. Its importance was based on the principles of the patriarchal order. The authority of the emperor, his officials and the position of the teacher and his father were in these countries indisputable. The basic attention was directed to moral education, which de facto subordinated the unit to authoritarian society, which

\footnotetext{
${ }^{24}$ Społeczność wietnamska w Polsce [The Vietnamese community in Poland], p. 37-38.

${ }^{25}$ M. Pietrasiak, "Prawi i utalentowani ludzie sa fundamentem państwa”. Polityka kulturalnooświatowa Wietnamu 1945-1976, ["The righteous and talented people are the foundation of the State". Cultural and educational policy of Vietnam 1945-1976], Łódź 2004, p. 13-17.
} 
followed rigorously established norms, ceremonies and customs of the wellestablished and enforced patterns of behavior. In the State of Vietnam successive ruling dynasties indicated either on Confucianism or Buddhism, rarely on Taoism as a source of educational value. In the late eighteenth century, the importance of education Confucian and Buddhist weakened but the serious breakdown occurred in the second half of the nineteenth century. During this time, the invaders began subordinate Vietnam to themselves, finally the French managed to subjugate Vietnam in the beginning of the next century. ${ }^{26}$

Colonial educational system has eliminated the Chinese writing and modeled on in Vietnamese version of scripture, as well as centuries-old cultural heritage of Vietnam, which was used primarily to denationalize Vietnamese people. New language based on the Latin language record was introduced, schools program was extended of knowledge regarding European, especially French culture. In the comparison with the previously mentioned system, colonial educational system was much more elitist and some researchers even pointing about the collapse of education in the Vietnamese society during that period. Since 1941, the Japanese gradually mastered the whole Indochina ${ }^{27}$ and after the Second World War there was a war between communist forces in Vietnam and France.

After the defeat of France, Vietnam was divided into the North and South part. In each of these countries, different education system was introduced. In North "folk" Vietnam education contained the context of communist ideology, in Southern Vietnam education was developed mainly under the influence of the United States of America, was more elitist and contained and promoted anti-communist matter and Western vision of the world. ${ }^{28}$ After the Vietnamese-American war, Vietnam united under communist rule, then there was a short-lived war with China. Starting from 1986, Vietnam has entered a phase of open-market economy and gradually opened up to the world also establishing contacts with capitalist countries.

After the Second World War, communist Vietnam began to pursue an educational reform at all levels of education, aiming to spread primary education, secondary and higher education in society. Relations with the Soviet

26 P. Zieliński, Wychowanie i systemy edukacyjne w Wietnamie na tle rozwoju historycznego $i$ kulturowego kraju (z uwzględnieniem podmiotowości w wychowaniu) [Education and educational systems in Vietnam against the background of the historical and cultural development of the country (including subjectivity in education)], Podstawy Edukacji. Podmiot w dyskursie pedagogicznym, 2010, 3, p. 210-231.

${ }^{27}$ Ibidem, s. 231-233.

${ }^{28}$ Ibidem, p 234-235 and P. Zieliński, Obraz edukacji w Wietnamie [Image of education in Vietnam], Pedagogika Społeczna, 2013, 1(47), p. 107-117. 
Union, as well as with other people's republics like Poland, contributed to the higher education and vocational training in the best universities of Central and Eastern Europe for many thousands of Vietnamese, mainly in the field of technical sciences. As reported by Wiesław Olszewski, only in years: 1955-1980 in the USSR qualifications gained more than 62,000 Vietnamese. ${ }^{29}$ In the mid-eighties Vietnam has introduced socio-economic reform called doi-moi, whereby the free market was established and private entrepreneurship began to develop, leaving political- ideological content somewhere in the background. ${ }^{30}$

In contemporary Vietnam, children can range from 3 months old to stay in nurseries, even more than two years, kindergarten is optional but since the age of six five-year primary school is mandatory, secondary school and then four gymnasium. The next step is three-year secondary school, three or four-year vocational school or a specialist one, the other option is take part in vocational training. After studies in secondary schools Vietnamese can study from four to six years, depending on the type of college. After that another possibility is the three-year colleges, after which there is the opportunity to complete two years of post-graduate studies. Vietnamese can also continue their education at a three-year doctoral program ${ }^{31}$. In Vietnam, there are 137 universities and 127 other institutions of higher education, part of which is private, moreover, the a significant amount of Vietnamese is willing to study outside their home country due to the non-recognition of national diplomas abroad. ${ }^{32}$

\section{Vietnamese Education in Poland}

In this section of the thesis, we will be closer to the Vietnamese minority education in Poland with regard to children from Polish-Vietnamese families. As mentioned above, certain aspects of stay and education Vietnamese in Poland were already described. Now, these issues will be presented wider, including some requested by Z. Kwieciński education processes.

${ }^{29}$ W. Olszewski, Historia Wietnamu [History of Vietnam], p. 433.

30 Ta Minh Tuan, Polityka zagraniczna Wietnamu w okresie odnowy (doi-moi): źródta i ewolucja [The foreign policy of Vietnam during the renewal (doi-moi): sources and evolution], AzjaPacyfik, 2002, 5, p. 54.

${ }^{31}$ P. Zieliński, Obraz edukacji w Wietnamie [Image of education in Vietnam], p. 119.

${ }^{32}$ Data from 2007. Vide: Społeczność wietnamska w Polsce [The Vietnamese community in Poland], p. 21-22. 
From the fifties to the seventies, Vietnamese constituted about $30 \%$ of the students - foreigners in Poland. Many of them settled in Poland, founded the family, in meantime maintaining contacts with the home country, learned not only Polish language but also Polish culture, making even translations of Polish literature into Vietnamese ${ }^{33}$. The first wave of Vietnamese migration to Poland and successive generations are directly related to the Vietnamese-educated and well-connected emotionally with the Poland. These people are related to each other multiannual acquaintances, sometimes by family, often through participation in the jobs created by their organization.

"Pan Tadeusz" translator, Vietnamese scientist Nguen Van Thai, is the president of the Association of Vietnamese in Poland called "Solidarity and Friendship", the largest of such organization, which also through contacts with the Polish authorities is trying to help the Vietnamese in Poland. The organization was founded in 1999, concentrates about eight hundred families or a few thousand people and seeks to integrate the Vietnamese community in Poland, providing them with the help of legal, financial and organizational areas. Organization conducts educational activities for Vietnamese, organize courses in Polish and Vietnamese, sporting and artistic activities also is issuing in Vietnamese ${ }^{34}$ the monthly magazine "Que Viet" which main goal is to popularize Polish culture among Vietnamese. Mentioned association also supports other organizations, among others Vietnam Language School, which teaches the mother tongue of the Vietnamese students in Polish schools. ${ }^{35}$ The oldest Vietnamese organization in Poland is Socio-Cultural Association of Vietnamese, formed in 1986, bringing together more than two hundred families. This Society has branches in several major Polish cities, among others in Krakow and Gdansk and their main goal is to cultivate and promote Vietnamese culture among the Polish society. To make that happen, Association organizes courses for Vietnamese children of mixed marriages, the celebration of the Vietnamese New Year, the Day of the Child, martial arts demonstrations, exhibitions, lectures and meetings and other actions. ${ }^{36}$ These two associations were founded by Vietnamese graduates of Polish universities.

33 For instance translation of "Pan Tadeusz" into Vietnamese was made by PHD Nguyen Van Thai. Vide: "Pan Tadeusz" po wietnamsku - wywiad $z$ dr. Nguyen Van Thai ["Pan Tadeusz” in Vietnamese - an interview with Dr. Nguyen Van Thai], http://www.polska-azja.pl/2012/ 08/06/pan-tadeusz-po-wietnamsku/, [access: 07.04. 2014].

${ }^{34} \mathrm{~K}$. Wysieńska, Organizacje wietnamskie i chińskie w Polsce [Vietnamese and Chinese organizations in Poland], Warszawa 2011, p. 16.

35 P. Zieliński, Edukacja międzykulturowa Wietnamczyków w Polsce [Intercultural education Vietnamese in Poland], p. 184.

${ }^{36}$ K. Wysieńska, Organizacje wietnamskie i chińskie w Polsce [Vietnamese and Chinese organizations in Poland], , p. 16. 
Differently in the case of the Association for Democracy and Pluralism in Vietnam - this is a political opposition organization and in fact, the Polish branch of this organization was founded in France by the anti-communist Nguyen Gia Kieng. Among its members we can find the former South Vietnamese government representatives. ${ }^{37}$ There is also direct connection to the "Solidarity and Friendship", Cultural Center of the Vietnam Thang Long and the Association of Vietnamese Buddhists. The last ones meet in the reply of Hanoi Temple of Literature pagodas, which is managed by them and which was araised in the mentioned center. Cultural Center itself was founded in Warsaw in 2003 and is associated with the Embassy of the Socialist Republic of Vietnam. The Centre is issuing a magazine called "Noi Vong Tay Lon", managing a website and selling newspaper "An Ninh" issued by the Ministry of Security SRW. In addition to the publishing activities, the Cultural Center is a meeting place for young Vietnamese willing to join dance team and participate in concerts. ${ }^{38}$ From on other hand, the VietForum Foundation wishes to activate professionally and practically Vietnamese in Poland and other European Union countries as well as in the Vietnam, mostly by providing knowledge about the know-how of democratic society functions. The goal is to help in better integration of the Vietnamese in the European Union but also share the knowledge of Vietnamese culture and society among citizens of the Union. ${ }^{39}$ Social and cultural activities and partially education in this field is also cultivated by other organizations, including: the Vietnamese Women's Club, Senior Citizens Club, Vietnamese Poets Club and the Vietnamese Catholic Community. ${ }^{40}$

Polish researchers tried, examine the community of Vietnamese immigrants in Poland in several respects, also associated with education. Ewa Nowicka-Rusek has investigated the problem of Vietnamese integration with Polish society in the early twenty-first century, referring to the 130 strong group of Vietnamese from Warsaw. One-sixth of the respondents were students and graduate students and the vast majority of people up to 35 years of age, employed in trade and gastronomy. Research conducted by scientist suggested that the Vietnamese second wave of migration behaved distrust of the research itself and people carrying them, as opposed to the elderly, educated, undergraduate and graduate students who have tried to help in these studies. Polish Language was known better by person above 45 years of age and under 25, than studied people aged 36-45 years. Much

\footnotetext{
${ }^{37}$ Ibidem.

38 Ibidem, p. 18.

${ }^{39}$ Ibidem.

${ }^{40}$ Ibidem, p. 16-17 and T. Halik, Polska i Wietnam [Poland and Vietnam], p. 111.
} 
worse was the level of Polish culture knowledge, as the Vietnamese respondents knew the names of a few famous Poles and in fact did not know the movies and Polish literature. One third of the respondents, mostly women, turned up only in an environment Vietnamese, the others dealed with Poles at work and school. About $90 \%$ of Vietnamese people was reading only the Vietnamese press, free time respondents spent among themselves, they were also celebrating their own Vietnamese feast. Mixed marriages were only a few and if - it was a marriage of Vietnamese with Polish women. More than half of the respondents positively evaluated the Vietnamese attitude of Poles towards each other, especially the educated and longer living in Poland. The elderly were characterized by a balanced opinion, younger people with a regulated status of residence permit showed even to the criticisms with respect to the Poles. They concerned the prevalence of drunkenness, violence and bureaucracy in our society. Summing up the results of these studies, it should be noted that the Vietnamese respondents poorly integrated into Polish society and characterized them primarily isolationist attitude. ${ }^{41}$

The legal status of Vietnamese children in Polish schools, like other children of foreigners is regulated by the Education System Law from 1991 and the Regulation of the Minister of Education from 2001. There are also several other documents, including MEN Regulation on the Framework of the Polish language courses for refugees in 2007. Children of parents who are foreigners without Polish citizenship and the right of permanent residence in Poland, which are between the ages of 7 to 16 years (if they did not previously completed high school, then to 18 years), should mandatory attend to Polish school. Their parents should pay for the education, but in practice this is rarely practiced. Vietnamese children which were brought to the Polish school, without knowledge of the Polish language, are typically directed to the lower classes in order to adapt until the time when they are able to effectively participate in these classes. The adaptation period is used to organize for them separate course curriculum, additional explanations, remedial classes after school, drawings are tolerated instead of written answers. ${ }^{42}$ In addition, parents often pay for tutoring children. Learning Polish language by the young Vietnamese attending school takes from 12 to 18 months. ${ }^{43}$ Vietnamese chil-

${ }^{41}$ E. Nowicka-Rusek, Adaptacja, asymilacja i izolacja Wietnamczyków w Warszawie [Adaptation, assimilation and isolation of the Vietnamese in Warsaw], [in:] Tolerancja i wielokulturowość - wyzwania XXI wieku [Tolerance and multiculturalism - XXI century challenges], eds A. Borowiak, P. Szarota, Warszawa 2004, p. 130-144.

${ }^{42}$ T. Halik, Polska i Wietnam [Poland and Vietnam], p. 112.

${ }^{43}$ I. Czerniejewska, Cudzoziemiec jako uczeń i student. Integracja w obszarze poznańskiej edukacji [The foreigner as a student. Integration in the Poznan area of education], [in:] Od gości do 
dren attending to first grade of primary school are quickly mastering the Polish grammar, spelling and most interesting, is not among them dyslexic, often winning competitions in spelling. ${ }^{44}$ This can be explained by traditional in their family environment Confucian upbringing, largely referring to memorization skills. Research shows that children in Vietnam quickly making progress in Polish schools. Their parents organize tutoring for them, moreover, are trying to isolate them in school from other children of Vietnamese nationality, believing that in this way quickly master the Polish language. Parents usually send them the lessons of religion, even though the children are usually different religion. They have their Polish names and parents are keen to integrate children with their school peers. However, outside of school, these children are involved in the lives of their families, mostly avoiding contacts with Polish peers. Their time is filled up by work for the family, taking care of siblings and taking private lessons. Older Vietnamese have the hope to improve the condition of the entire family, due to a better knowledge of the new reality by the youngest. Vietnamese children are disciplined, polite but often do not have their own opinion or they are hiding them and their knowledge is presented in school is a reproductive. The patriarchal structure of Vietnamese families, strict compliance and adherence to their role in the family and community also results in a lack of pranks and youth rebellions of the nations, in contrast to the Polish youth. ${ }^{45}$

Research conduct by Aneta Makowska were concerned about the education of children from mixed Polish-Vietnamese families, living in Czestochowa and the surrounding smaller towns. A. Makowska has investigated 23 couples that are in the age range from 31 to 40 years, of which only two were marriages were conducted by Polish man with Vietnamese, which confirms the trend previously stated in studies of E. Nowicka-Rusek. Most couples have marital internship from 11 to 15 years, men were older than women from 5 to 10 years, the Vietnamese have settled legally stay in Poland, couples usually have professional training or secondary one. Marriages held together 46 children, of which slightly more boys and more than two-thirds of children have attended primary school, the other for high school. ${ }^{46}$ Makowska has also investigated the attitudes of 62 neighbors with

sąsiadów. Integracja cudzoziemców spoza Unii Europejskiej w Poznaniu w edukacji, na rynku pracy $i w$ opiece zdrowotnej [From guests to neighbors. Integration of foreigners from outside the European Union in Poznan in education, the labor market and health care], eds N. Bloch, E.M. Goździak, Poznań 2010, p. 62.

${ }^{44}$ T. Halik, Polska i Wietnam [Poland and Vietnam], p. 112.

${ }^{45}$ Ibidem, p. 111-115.

46 These and further data from A. Makowska research, were quoted in: P. Zieliński, Edukacja międzykulturowa Wietnamczyków w Polsce [Intercultural education Vietnamese in Po- 
respect to Polish-Vietnamese marriages. Neighborly help and social contacts maintained 26 Poles, the vast majority had a positive attitude to married couples surveyed, although a few people did not want to have anything to do with them and in the statements of several of the respondents racist elements were visible. More than half of Polish neighbors knew the location and socio-political system of Vietnam, but half of them were unable to say anything more to add about Vietnam and its culture. ${ }^{47}$

Very interesting are the results of studies directly related to training and education, including religious education of the children in the surveyed Polish-Vietnamese families. These couples have two to three children who have Polish names, but the family names have always after their fathers. All were baptized, almost all were in communion, fifth already undergone confirmation. The children participated regularly in religious education classes, masses and other forms of Catholic worship. These findings also confirm earlier trends of Vietnamese behavior in Poland. In 37 interviews with children, it was showed that for three-quarters of these parents played a vital role associated with national identity, the other children had a sense of "being freaks". Almost all children knew Vietnamese language, all were in Vietnam and got to know their relatives, about one-third wanted to stay longer in Vietnam, a fifth wanted to change their faith to Buddhism. ${ }^{48}$ Makowska has also investigated school teachers of children from PolishVietnamese families and has captured a trend related to the reception of these children at school by their peers. As many as nine-tenths of the surveyed teachers did not recognized the acts of intolerance towards children of mixed marriages. Teachers were young and working in the profession for a short period of time, moreover indicating the humanistic and democratic values education. However almost all the children of these marriages had experience with expressions of intolerance and aggression from their Polish peers at school and more than two-thirds were beaten, all of them were verbally abused and insulted in other ways. ${ }^{49}$

Analyzing the patterns behavior of these children parents with regard to their nationality, you can see a regularity. Vietnamese Parent in the foreground and at the same level of validity sees the value of education, as a child obedience, respect for elders and good academic performance, fur-

land], p. 187-189; A. Makowska has completed under my direction in 2009 the AJD, thesis on "Education of children living in families coming from Poland Polish-Vietnamese".

${ }^{47}$ P. Zieliński, Edukacja międzykulturowa Wietnamczyków w Polsce [Intercultural education Vietnamese in Poland], p. 187-189.

48 Ibidem.

${ }^{49}$ Ibidem, p. 189. 
ther places take the happiness of the child and having friends, as well as the realization of their dreams considers as insignificant. In the case of a Pole parent trend is almost reversed. Happiness of the child, the realization of his dreams, good grades and having friends are the most important, respect for elders and obedience were in the background. The shared value and high position in the opinion of the both nationalities parents are high notes among the set of educational, although the Vietnamese put it a little bit higher. ${ }^{50}$ In light of the presented differences in the perception of the core values in education in Polish-Vietnamese families, conflict can occur between spouses, which may also be the cause of education in separate road for spouses.

An important role in intercultural education of migrant children in Poland, including children from families of Vietnamese but also their Polish peers and their families, moreover teachers and local government play the integration meetings and workshops conducted by various organizations. A few examples of how Project Development Education Program under the Foreign Assistance of the Ministry of Foreign Affairs in 2006 has helped, I gave in a previous publication. ${ }^{51}$ Another interesting example is the program training "Children and young Vietnamese in the Polish system of education", organized by the Foundation for Art Arteria within 2 Vietnamese Films Festival in Warsaw in 2008. This training was related to educational work with children in schools and Vietnamese intercultural educational among the leading classes were: Teresa Halik, Ewa Grabowska, Kinga Bialek, Emilia Skiba and invited Vietnamese guests. During the meetings presenters to were trying to convey knowledge about the culture of Vietnam and Vietnamese in Poland, about the education system in Vietnam, about the needs of children and young people of Vietnam in the Polish schools, on the requirements for teachers and educators who work with them, including the education of intercultural competence. It was mainly about mastering intercultural communication, cultural negotiation, conflict resolution and intercultural integration of children from different cultures. ${ }^{52}$

Another interesting example is a School Guide for foreign students and their parents developed within the project "Let's Meet - Lesznowola Municipality of many cultures". Guidance has been prepared in several languages: Vietnamese, Chinese and Polish. It contains in addition to the written word, colorful illustrations and clear tables linked directly to the content. Among the

\footnotetext{
50 Ibidem, p. 188.

${ }^{51}$ Ibidem, p. 189-190.

${ }^{5}$ Data obtained from Substantive Reports of Arteria Art Foundation in 2009 and mentioned training program.
} 
topics discussed in this guide are: greeting, the system of education in Poland, the calendar of the school year, the grading system with the names of degrees of objects and behaviors, ways to make friends with peers, patterns of behavior in the school, the role of the student in the school and its desirable characteristics, behavior in difficult situations, Issue correspondence with parents, school equipment and other issues. ${ }^{53}$

An important role in the development of intercultural education in Poland are not only websites, such as a website established in 2006 Intercultural Education Foundation" 54 , but also the electronic magazine as "Multicultural Centre in Warsaw", the newsletter of the Warsaw Multicultural Centre issued by the Other Space Foundation, which the number 5 presents the several articles devoted to the Vietnamese but also profiles of Polish organizations multicultural education and intercultural.

\section{Summary}

Analyzing the above data and the results of research, it should be noted that the Vietnamese immigrants family in Poland and the Polish-Vietnamese families are patriarchal and character of education or at least the characteristics of Confucian education, regardless of their religion. Nurture of traditional values, such as respect for elders, obedience, working for the family threatens to become many different forms, also as an effective school-work of children in these families are dominant in those families. This is not only result of the Confucian education, but also the family nature of Vietnamese society and the fundamental role of the family in the survival of the Vietnamese people, assailed and exterminated by foreign powers since ancient times. In this context it also reveals the Taoist education element, as is some flexibility characterizes the Vietnamese is not based on rigid principles of Confucianism, but on Taoism to be precisely. According to the Taoism thesis man who is holding a trait of flexibility can survive even in very difficult conditions, natural and socio- political. 55

${ }^{53}$ K. Białek, M. Jarmóż, A. Ośko, Poradnik szkolny dla uczniów cudzoziemskich i ich rodziców [School Guidance for foreign students and their parents], Guidance developed within the project "Let's Meet - Lesznowola Municipality of many cultures", available in three languages on the Foundation's Intercultural Education in pdf files: http://www.miedzykulturowa. org.pl/cms / en /'s meet-Aug-projekt.html, [access: 22.04.2014].

54 Its Internet address: http:/ / www.miedzykulturowa.org.pl/.

55 P. Zieliński, Wzorce starochińskiego humanizmu w edukacji [Patterns of early Chinese humanism in education ], Prace Naukowe Akademii im. Jana Długosza w Częstochowie. Pedagogika, 2013, XXII, p. 90. 
In the families of Vietnamese migrants and mixed education is the primacy of collectivist over individualist, though probably a Vietnamese parent recognizes and supports the efforts of spiritual self-realization and their religious self-growing children, usually according to the canon of Buddhist education. We must also remember that the Vietnamese attitude towards religion is a syncretic, Neo-Confucianism thinkers have sought to demonstrate a single source of all religions, hence it takes a large religious tolerance peoples associated with the culture and philosophical- religious systems of the Far East. Tolerance is a characteristic defining for intercultural education.

The Vietnamese migrants from the first wave clearly integrated themselves (in terms of both economic as well as social and cultural) with the Polish society and it can be concluded that intercultural education as a strategy for treatment of migrants was a certain success here. Those migrants were assumed in the past with dignity and fairly, Poland was providing them with the right conditions in the process of inculturation. ${ }^{56}$ Educated Vietnamese were also able independently solve problems and pursue acculturation assumptions of intercultural education, as documented above. Those who were not willing to integrate, came from the second wave of migration, were definitely less educated, had other goals in life, and they were not welcome guests in our country. ${ }^{57}$ Similar conclusions regarding the differences in the integration of Vietnamese society discover Aleksandra Grzymała-Kazłowska, highlighting the significant role in the integration of children of Vietnamese families already raised in Poland and Vietnamese associations. ${ }^{58}$

Difficult to implement are the demands of intercultural education which have been largely realized in education Vietnamese minority in Poland, the coming of the first wave of migration and it has become possible due to not fully conscious in this regard Polish socialist politics and their own efforts, with some help associations and NGOs. Finally, this success is not a result of a conscious policy of the modern Polish state.

56 Of course it was a conditional ideologically linked internationalist policy objectives of the then socialist bloc countries. Internationalist education in the context of intercultural pedagogy was examined by B. Śliwerski. Vide: B. Śliwerski, Wspótczesne teorie i nurty wychowania [Contemporary theories and trends of education], p 285-288.

${ }^{57}$ M. Pawlak, N. Ryabinska, Dlaczego uchodźcy "nie chca" integrować się w Polsce? Ocena skuteczności programów integracyjnych z punktu widzenia uchodźców [Why refugees "do not want" to integrate in Poland? Assessment of the effectiveness of programs of integration from the perspective of refugees ], [in:] Przystanek Polska. Analiza programów integracyjnych dla uchodźców [Stop Poland. Analysis of integration programs for refugees], eds W.J. Frelak, W. Klaus, J. Wiśniewski, Warszawa 2007, p. 129-131.

58 A. Grzymała-Kazłowska, Między jednością a wielością [Between unity and multiplicity], p. 262. 


\section{BIBLIOGRAPHY}

Białek K., Jarmóż M., Ośko A., Poradnik szkolny dla uczniów cudzoziemskich i ich rodziców [School Guidance for foreign students and their parents], Guidance developed within the project "Let's Meet - Lesznowola Municipality of many cultures", available in three languages on the Foundation's Intercultural Education in pdf files: http:/ / www.miedzykulturowa.org.pl/cms / en /'s meet-Aug-projekt.html, [access: 22.04. 2014].

Chodubski A., Wyzwania migracyjne we wspótczesnej Europie [Migration Challenges in Contemporary Europe], Przegląd Polsko-Polonijny, 2011, 2.

Czerniejewska I., Cudzoziemiec jako uczeń i student. Integracja w obszarze poznańskiej edukacji [The foreigner as a student. Integration in the Poznan area of education], [in:] Od gości do sąsiadów. Integracja cudzoziemców spoza Unii Europejskiej w Poznaniu w edukacji, na rynku pracy $i$ w opiece zdrowotnej [From guests to neighbors. Integration of foreigners from outside the European Union in Poznan in education, the labor market and health care], eds N. Bloch i E.M. Goździak, Centrum Badań Migracyjnych UAM, Poznań 2010.

Gromkowska-Melosik A., Mniejszość muzutmańska w Szwecji: między ekstremistycznym izolacjonizmem a procesami reprodukcji ekonomicznej [Muslim minority in Sweden: between extremist isolationism and economic reproduction processes], Studia Edukacyjne, 2013, 26.

Grzymała-Kazłowska A., Między jednościa a wielością: integracja odmiennych grup i kategorii imigrantów w Polsce [Between unity and multiplicity: the integration of the different groups and categories of migrants in Poland], Ośrodek Badań nad Migracjami WNE UW, Warszawa 2008.

Halik T., Polska i Wietnam [Poland and Vietnam], [in:] Migranci w polskim spoteczeństwie [Migrants in the Polish society], eds T. Halik, A. Kosowicz, M. Marek, Stowarzyszenie Vox Humana, Warszawa 2009.

Kwieciński Z., Socjopatologia edukacji [Sociopathology of education], Wydawnictwo Edytor, Warszawa 1992.

Melosik Z., Teoria i praktyka edukacji wielokulturowej [Theory and practice of multicultural education], Oficyna Wydawnicza Impuls, Kraków 2007.

Nikitorowicz J., Pogranicze. Tożsamość. Edukacja międzykulturowa [Borderland. Identity. Intercultural Education], „Trans Humana” Wydawnictwo Uniwersyteckie, Białystok 1995.

Nikitorowicz J., Edukacja międzykulturowa [The Intercultural Education], [in:] Encyklopedia pedagogiczna XXI wieku, [Pedagogical Encyclopedia XXI Century], vol. 1, A-F, ed. T. Pilch, Wydawnictwo Akademickie Żak, Warszawa 2003.

Nikitorowicz J., Edukacja międzykulturowa w przestrzeni regionalnej, europejskiej i planetarnej [Intercultural Education in the regional, European and planetary], [in:] Nauki pedagogiczne w Polsce. Dokonania, problemy, wspótczesne zadania, perspektywy [Pedagogical Science in Poland. Achievements, problems, contemporary tasks, perspectives], eds E. Lewowicki, M.J. Szymański, Wydawnictwo Naukowe AP, Kraków 2004.

Nowicka-Rusek E., Adaptacja, asymilacja i izolacja Wietnamczyków w Warszawie [Adaptation, assimilation and isolation of the Vietnamese in Warsaw], [in:] Tolerancja $i$ wielokulturowość - wyzwania XXI wieku [Tolerance and multiculturalism - XXI century challenges], eds A. Borowiak, P. Szarota, Wydawnictwo SWPS Academica, Warszawa 2004. 
Olszewski W., Historia Wietnamu [History of Vietnam], Wydawnictwo Zakładu Narodowego im. Ossolińskich, Wrocław 1991.

Palka S., Badania z pedagogiki i pogranicza innych nauk [Research in Pedagogy and borderline other sciences], [in:] Podstawy metodologii badan w pedagogice [Fundamentals of research methodology in education], ed. S. Palka, Gdańskie Wydawnictwo Psychologiczne, Gdańsk 2010.

"Pan Tadeusz" po wietnamsku - wywiad $z$ dr. Nguyen Van Thai ["Pan Tadeusz" in Vietnamese - an interview with Dr. Nguyen Van Thai], http://www.polska-azja.pl/2012/ 08/06/pan-tadeusz-po-wietnamsku/, [access: 07.04.2014].

Pawlak M., Ryabinska N., Dlaczego uchodźcy "nie chca" integrować się w Polsce? Ocena skuteczności programów integracyjnych z punktu widzenia uchodźców [Why refugees "do not want" to integrate in Poland? Assessment of the effectiveness of programs of integration from the perspective of refugees], [in:] Przystanek Polska. Analiza programów integracyjnych dla uchodźców [Stop Poland. Analysis of integration programs for refugees], eds W.J. Frelak, W. Klaus, J. Wiśniewski, Instytut Spraw Publicznych, Warszawa 2007.

Pietrasiak M., "Prawi $i$ utalentowani ludzie sa fundamentem państwa”. Polityka kulturalnooświatowa Wietnamu 1945-1976, ["The righteous and talented people are the foundation of the State". Cultural and educational policy of Vietnam 1945-1976], Wydawnictwo „Ibidem”, Łódź 2004.

Społeczność wietnamska w Polsce. Polityka migracyjna Wietnamu. Raport [The Vietnamese community in Poland. Migration policy in Vietnam. The report], Migration Analysis Division. Migration Policy Department. Ministry of Interior and Administration, Warsaw, June 2007.

Szkudlarek T., Pedagogika międzykulturowa [Intercultural pedagogy], [in:] Pedagogika [The pedagogy], vol. 1, eds Z. Kwieciński, B. Śliwerski, Wydawnictwo Naukowe PWN, Warszawa 2004.

Szymańska-Matusiewicz G., Niezupetnie bliźniacze społeczności. Wietnamczycy w Polsce $i$ Czechach [Not exactly the twin communities. Vietnamese in Poland and the Czech Republic], Centrum Studiów Polska - Azja, http://www.polska-azja.pl/2013/ 04/22/g-szymanska-matusiewicz-niezupelnie-blizniacze-spolecznosci-wietnamczy cy-w-polsce-i-czechach/, [access: 31.03.2014].

Śliwerski B., Wspótczesne teorie i nurty wychowania [Contemporary theories and trends of education], Oficyna Wydawnicza Impuls, Kraków 1998.

Ta Minh Tuan, Polityka zagraniczna Wietnamu w okresie odnowy (doi-moi): źródła i ewolucja [The foreign policy of Vietnam during the renewal (doi-moi): sources and evolution], Azja-Pacyfik, 2002, 5.

Wysieńska K., Organizacje wietnamskie i chińskie w Polsce [Vietnamese and Chinese organizations in Poland], Instytut Spraw Publicznych, Warszawa 2011.

Zieliński P., Edukacja międzykulturowa Wietnamczyków w Polsce z uwzględnieniem dzieci $z$ rodzin polsko-wietnamskich [Intercultural education Vietnamese in Poland also regarding children from Polish-Vietnamese families], Prace Naukowe Akademii im. Jana Długosza w Częstochowie, Pedagogika, 2010, XIX.

Zieliński P., Obraz edukacji w Wietnamie [Image of education in Vietnam], Pedagogika Społeczna, 2013, 1(47).

Zieliński P., Wychowanie i systemy edukacyjne w Wietnamie na tle rozwoju historycznego i kulturowego kraju (z uwzględnieniem podmiotowości w wychowaniu) [Education and educational systems in Vietnam against the background of the historical and cultural 
development of the country (including subjectivity in education)], Podstawy Edukacji. Podmiot w dyskursie pedagogicznym, 2010, 3.

Zieliński P., Wzorce starochińskiego humanizmu w edukacji [Patterns of early Chinese humanism in education], Prace Naukowe Akademii im. Jana Długosza w Częstochowie. Pedagogika, 2013, XXII. 